\title{
GROWTH AND PHYSIOLOGICAL RESPONSES OF TREE SPECIES (Hymenaea courbaril L., Peltophorum dubium (Spreng.) Taub. and Myroxylon peruiferum L. F.) EXPOSED TO DIFFERENT COPPER CONCENTRATIONS IN THE SOIL ${ }^{1}$
}

\author{
Daniele Maria Marques ${ }^{2 *}$, Adriano Bortolotti Silva ${ }^{3}$, José Ricardo Mantovani ${ }^{3}$ Dalvana Sousa Pereira ${ }^{3}$ \\ and Thiago Corrêa Souza ${ }^{4}$
}

\footnotetext{
${ }^{1}$ Received on 13.06.2017 accepted for publication on 01.03.2018.

${ }^{2}$ Universidade Federal de Lavras, Programa de Pós-Graduação em Botânica Aplicada, Lavras, MG-Brasil. E-mail: $<$ danimarques.bio@gmail.com>.

${ }^{3}$ Universidade José do Rosário Vellano, Instituto de Ciências Agrárias, Alfenas, MG-Brasil. E-mail: <adriano.silva@unifenas.br>, <jose.mantovani@unifenas.br> and $<$ DalvanaSousa@hotmail.com>.

${ }^{4}$ Universidade Federal de Alfenas, Instituto de Ciências da Natureza, Alfenas, MG-Brasil. E-mail: <thiagonepre@hotmail.com>. *Corresponding author.
}

\begin{abstract}
Copper $(\mathrm{Cu})$ is an essential micronutrient for plants. However, when in excess, it becomes phytotoxic. In this context, the objective of this study was to evaluate the growth and physiological responses of tree species exposed to different copper concentrations in the soil. Three experiments were carried out, one for each forest species under study: Myroxylon peruiferum (“Óleo Bálsamo”), Hymenaea courbaril (“Jatobá”) and Peltophorum dubium ("Canafístula"), with the same doses of copper (0, 50, 100, 200 and $\left.400 \mathrm{mg} \mathrm{kg}^{-1}\right)$. The experimental design was in randomized blocks (DBC), with five copper concentrations and four replicates. The plants were grown on soil substrate packed in $8-\mathrm{dm}^{3}$ pots and kept in a greenhouse for 90 days. Biometric measurements, chlorophyll, antioxidant enzymes and copper content in tissues were evaluated. Copper did not influence the vegetative growth of the species studied. The content of chlorophyll "a" was reduced with increasing copper concentrations in the soil. H. courbaril had 56 to $92 \%$ copper retained in the roots, and the same behavior was observed for P. dubium (77-91\%) and M. peruiferum (19-64\%). In the three species studied, there was copper bioaccumulation, mainly in the roots, possibly as a metal tolerance strategy, preserving the most active tissues and the photosynthetic machinery. $\mathrm{Cu}$ translocation from roots to shoot was very restricted in all species. This behavior, associated with the increase in the activity of some antioxidant enzymes in plants, may indicate the phytoremediation potential of the studied species.
\end{abstract}

Keywords: Antioxidant enzymes; Bioaccumulation; Heavy metal.

\section{CRESCIMENTO E RESPOSTAS FISIOLÓGICAS DAS ESPÉCIES ARBÓREAS Hymenaea courbaril L., Peltophorum dubium (Spreng.) Taub. e Myroxylon peruiferum L. $F$. EXPOSTAS A DIFERENTES CONCENTRAÇÕES DE COBRE NO SOLO}

RESUMO - O cobre (Cu) é um micronutriente essencial aos vegetais, mas em excesso torna-se fitotóxico para as plantas. Nesse contexto, o objetivo deste trabalho foi avaliar o crescimento e as respostas fisiológicas de espécies arbóreas expostas a diferentes concentrações de cobre no solo. Foram realizados três experimentos, sendo um para cada espécie florestal em estudo: Myroxylon peruiferum (Óleo Bálsamo), Hymenaea courbaril (Jatobá) e Peltophorum dubium (Canafistula), com as mesmas doses de cobre (0, 50, 100, 200 e $400 \mathrm{mg}$ $\left.\mathrm{kg}^{-1}\right)$. O delineamento para os experimentos foi em blocos casualizados (DBC) com cinco concentrações de $\mathrm{Cu}$ e quatro repetições. As plantas foram cultivadas em substrato de solo acondicionados em vasos de 8 $d^{3}$ e mantidas em casa-de-vegetação por 90 dias. Foram avaliadas medidas biométricas, clorofila, enzimas 
antioxidantes e o teor de Cu nos tecidos. O Cu não influenciou no crescimento vegetativo das espécies estudadas. O teor de clorofila " a" foi reduzido com o aumento do Cu no solo. $\boldsymbol{H}$. courbaril apresentou 56 a $92 \%$ do Cu retido nas raizes, ocorrendo o mesmo comportamento para P. dubium (77-91\%) e M. peruiferum (1964\%). Nas três espécies em estudo houve bioacumulação do Cu nas raízes, possivelmente como estratégia de tolerância a metal, preservando os tecidos mais ativos e a maquinaria fotossintética. A translocação do Cu das raizes para a parte aérea foi muito restrita em todas as espécies. Este comportamento associado com o aumento da atividade de algumas enzimas do sistema antioxidante nas plantas pode indicar o potencial fitorremediador das espécies estudadas.

Palavras-Chave: Enzimas antioxidantes; Bioacumulação; Metal pesado

\section{INTRODUCTION}

Copper $(\mathrm{Cu})$ is an essential micronutrient for plant development, participating in metabolism and being a structural part of some enzymes (Gautam et al., 2016). The concentration of $\mathrm{Cu}$ in plant tissues may vary depending on plant species, development stage and environmental factors (Yruela, 2009). Marschner (1995) reported that, in general, $\mathrm{Cu}$ concentration in plant tissues is between 1 and $5 \mu \mathrm{g} \mathrm{g}^{-1}$ dry weight.

$\mathrm{Cu}$ contamination in soils due to anthropic activities such as the arbitrary use of pesticides, fungicides, wastewater-based irrigation, industrialization, urbanization, mineralization and the use of urban waste has caused an increase in the levels of this element (Mateos-Naranjo et al., 2013). High copper concentrations in the biosphere cause a reduction in the environmental quality and vitality of living beings, in addition to high persistence in the environment (Nagajyoti et al., 2010; Ali et al., 2013; Stankovic et al., 2014).

In plants, excess $\mathrm{Cu}$ can lead to physiological, biochemical and morpho-anatomical disturbances in plants, causing inhibition of their development (SánchezPardo et al., 2014; Gautam et al., 2016), besides oxidative stress in plants, due to the increase in the production of highly toxic oxygen free radicals that damage lipids and cell membrane proteins, amino acids and nucleic acids (Thounaojam et al., 2012; Moraes et al., 2015), decreasing agricultural productivity (Gao et al., 2010).

Plants have different mechanisms to grow in soils contaminated with $\mathrm{Cu}$. The accumulation of this heavy metal in the roots (Malik and Biswas, 2012) is one of the main tolerance strategies to prevent its translocation to the photosynthetic tissues (Cambrollé et al., 2013), which can alter chlorophyll levels in the leaves. The vacuole and the ion flow to the plasma membrane are channels that may decrease the presence of heavy metals in the cytoplasm (Sheoran et al., 2010). Other mechanisms promote the binding of carboxylic acids, amino acids, peptides, metallothioneins and phytochelatins with heavy metals (Sheoran et al., 2010), which act in the sequestration and inactivation of metallic ions before their entry into the cytoplasm (Hossain et al., 2012).

$\mathrm{Cu}$ toxicity can cause oxidative stress in plants and increase the production of oxygen free radicals, which are highly toxic (Yruela, 2009). Plants designed to prevent the production of these free radicals produce antioxidant enzymes such as superoxide dismutase, catalase, ascorbate peroxidase and guaicol peroxidase (Adrees et al., 2015). The knowledge of the behavior of plant antioxidant enzymes exposed to heavy metals is important for the selection and use of tree species in the recovery of degraded areas.

In this context, the objective of this study was to evaluate the growth and physiological responses of the tree species Hymenaea courbaril ("Jatobá"), Peltophorum dubium ("Canafístula") and Myroxylon peruiferum ("Óleo Bálsamo"), subjected to different copper concentrations in the soil.

\section{MATERIALAND METHODS}

\subsection{Growth conditions and experimental design}

The experiments were conducted in a greenhouse with a plastic cover and $50 \%$ shading $\left(\right.$ Sombrite ${ }^{\circledR}$ ), at Universidade José do Rosário Vellano (UNIFENAS), Alfenas, Minas Gerais, with geographic coordinates: $21^{\circ} 25^{\prime} 45^{\prime \prime} \mathrm{S}, 45^{\circ} 56^{\prime} 50^{\prime \prime} \mathrm{W}$, and average altitude of $881 \mathrm{~m}$. In the growing environment, the average temperature was $28.9^{\circ} \mathrm{C}$ and relative humidity $(\mathrm{RH})$ around $68 \%$. The substrate consisted of a medium-acidity Eutrophic Haplic Cambisol with a $0-20 \mathrm{~cm}$ deep layer, air dried, crushed, sieved (4-mm mesh sieve), homogenized and packed in $8-\mathrm{dm}^{3}$ pots. The results of soil chemical analysis are shown in Table 1.

Revista Árvore. 2018;42(2):e420202 
Table 1 - Chemical characteristics of the soil before the application of copper. Tabela 1 - Características químicas do solo antes da aplicação do cobre.

\begin{tabular}{|c|c|c|c|c|c|c|c|c|c|c|c|c|}
\hline $\mathrm{pH}\left(\mathrm{H}_{2} \mathrm{O}\right)$ & P(Mehlich) & K & $\mathrm{Ca}^{+2}$ & $\mathrm{Mg}^{+2}$ & $\mathrm{Al}^{+3}$ & $\mathrm{SB}^{*}$ & $\mathrm{~V}^{*}$ & M.O.* & $\mathrm{Zn}$ & $\mathrm{Fe}$ & $\mathrm{Mn}$ & $\mathrm{Cu}$ \\
\hline & $\mathrm{mg} \mathrm{dm}^{-3}$ & - & $-\mathrm{cn}$ & $\mathrm{dm}^{-3}$ & & - & $\%$ & dag $k^{-1}$ & 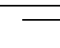 & & $\mathrm{dm}^{-3}-$ & \\
\hline 5.2 & 7.5 & 2.1 & 35.9 & 11.4 & 1.0 & 49.4 & 60 & 26.1 & 1.1 & 29.7 & 19.8 & 2.3 \\
\hline
\end{tabular}

* Sum of bases (SB); base saturation index (V); organic matter (M.O.). (Source: the author)

Three experiments were carried out, one for each tree species studied: "Jatobá” (Hymenaea courbaril), "Canafístula" (Peltophorum dubium) and "Óleo Bálsamo" (Myroxylon peruiferum), which were exposed to different copper concentrations $\left(0,50,100,200\right.$ and $\left.400 \mathrm{mg} \mathrm{kg}^{-1}\right)$. The experimental design was in randomized blocks (RBD), consisting of five copper concentrations and four replications, conducted from October 2013 to February 2014.

Sowing was carried out in $180-\mathrm{cm}^{3}$ tubes, filled with commercial substrate Plantmax ${ }^{\circledR}$ and base fertilization consisting of $3 \mathrm{~kg} \mathrm{~m}^{-3}$ Yorim Master ${ }^{\circledR}\left(16 \% \mathrm{P}_{2} \mathrm{O}_{5}, 18 \%\right.$ $\mathrm{Ca}, 7 \% \mathrm{Mg}$ ). Three cover fertilization procedures were carried out at 45, 60 and 90 days after sowing with: 20 $\mathrm{g}$ of $\mathrm{N}$ and $15 \mathrm{~g}$ of $\mathrm{K}_{2} \mathrm{O}$, with urea and potassium chloride, respectively, as the source, which were dissolved in $10 \mathrm{~L}$ water, and $10 \mathrm{~mL}$ solution per plant were applied.

Plants with approximately 120 days of age from the three species under study were transferred to the pots. The different copper concentrations $\left(\mathrm{CuSO}_{4} .5 \mathrm{H}_{2} \mathrm{O}\right)$ were applied to the soil at 30 days of transplanting. During the conduction of the experiment, soil moisture was controlled every two days, by weighing the pots and replacing the water, to maintain soil moisture at $70 \%$ of the retention capacity.

\subsection{Biomass and biometric measurements}

At 90 days after copper application, height (A), stem diameter (SD), shoot dry matter (SDM) and root dry matter (RDM) were evaluated. Measurements were established using a caliper and tape measure. To obtain leaf dry matter, stems and roots were washed to remove any particles, and brought to a forced circulation oven at $60^{\circ} \mathrm{C}$ until reaching constant weight.

\subsection{Chlorophyll content, antioxidant enzymes and copper content}

For the analysis of chlorophyll content, two fully expanded leaves were collected, by replication; $0.1 \mathrm{~g}$ leaf was ground in $5 \mathrm{~mL}$ of $80 \%$ acetone. The extract was filtered on glass wool and the volume was made up to $10 \mathrm{~mL}$ with $80 \%$ acetone.
Readings were performed at $663 \mathrm{~nm}$ and $647 \mathrm{~nm}$, using a light absorption spectrophotometer (Arnon, 1949). For chlorophyll calculations ( $\mu$ g chlorophyll $\mathrm{mL}^{-1}$ ), the following equations were used: chlorophyll a $\left[\left(12.25 \mathrm{xA}_{663}\right)-\left(2.79 \mathrm{xA}_{647}\right)\right]$; chlorophyll b $\left[\left(21.50 \times \mathrm{A}_{647}\right)-\left(5.10 \mathrm{xA}_{663}\right)\right]$; total chlorophyll (chlorophyll $a+$ chlorophyll $b$ ).

The enzymatic analysis on the leaves was according to Souza et al. (2012) and the supernatants collected were used in the analysis of all enzymes. The activities of the enzymes were evaluated spectrophotometrically and expressed in milligrams (mg) of proteins, which were determined by the method of Bradford (1976), using a standard curve of bovine serum albumin (BSA).

The activity of superoxide dismutase (SOD, EC 1.15.1.1) was evaluated by the ability to inhibit the photoreduction of nitro blue tetrazolium (NBT), proposed by Giannopolitis and Ries (1977). Catalase (CAT, EC 1.11.1.6) activity was determined by the consumption of $\mathrm{H}_{2} \mathrm{O}_{2}$ at $240 \mathrm{~nm}$ for 3 minutes (Havir and Mchale, 1987). The activity of ascorbate peroxidase (APX,EC 1.11.1.11) was determined by monitoring the oxidation of ascorbate at $290 \mathrm{~nm}$ for 3 minutes (Nakano and Asada, 1981). The activity of guaiacol peroxidase (GPX, EC 1.11.1.7) was determined by the oxidation of guaiacol at $470 \mathrm{~nm}$, according to Lin and Wang (2002), with modifications. All analyses were performed at the end of the ninety days of culture. Cu contents in plant tissues and soil were quantified by atomic absorption spectrophotometry, according to Carmo et al. (2000).

\subsection{Data analysis}

For all analyzed variables, the means and \pm standard error (SE) were calculated. For statistical analysis of the results, when significant, linear and non-linear regression analysis were used, as well as ANAVA, using the Sisvar software (version 4.3) (Universidade Federal de Lavras, Lavras, Brazil).

\section{RESULTS}

\subsection{Biomass and biometric measurements}

The use of copper $(\mathrm{Cu})$ in the different species did not present a significant effect $(\mathrm{p}>0.05)$ on plant growth (Table 2). H. courbaril had a mean height of $(\mathrm{H}=74.00 \mathrm{~cm})$, 
Table 2 - Plant height (H), stem diameter (SD), shoot dry matter (SDM) and root dry matter (RDM), for the species Hymenaea courbaril, Peltophorum dubium and Myroxylon peruiferum grown in soil with $\mathrm{Cu}$.

Tabela 2 - Altura das plantas (A), diâmetro do caule (DC), massa seca da parte aérea (MSPA), massa seca da raiz (MSR), das espécies Hymenaea courbaril, Peltophorum dubium e Myroxylon peruiferum, cultivadas em solo com Cu.

\begin{tabular}{|c|c|c|c|c|c|}
\hline Species & $\mathrm{Cu}\left(\mathrm{mg} \mathrm{Kg}{ }^{-1}\right)$ & $\mathrm{H}(\mathrm{cm})^{*}$ & $\mathrm{SD}(\mathrm{cm})^{*}$ & $\operatorname{SDM}(\mathrm{g})^{*}$ & RDM (g)* \\
\hline & 0 & $72.50 \pm 5.06$ & $1.10 \pm 0.03$ & $27.98 \pm 8.28$ & $13.13 \pm 2.95$ \\
\hline & 50 & $75.00 \pm 7.61$ & $1.13 \pm 0.13$ & $34.02 \pm 3.65$ & $11.38 \pm 2.47$ \\
\hline \multirow[t]{3}{*}{ H. courbarilL. } & 100 & $75.75 \pm 7.08$ & $1.17 \pm 0.27$ & $30.06 \pm 11.44$ & $12.97 \pm 5.81$ \\
\hline & 200 & $79.00 \pm 7.34$ & $1.25 \pm 0.08$ & $33.48 \pm 3.43$ & $12.86 \pm 1.82$ \\
\hline & 400 & $67.75 \pm 2.63$ & $1.21 \pm 0.21$ & $28.83 \pm 11.67$ & $12.81 \pm 6.94$ \\
\hline Mean & - & $74.00 \pm 4.20$ & $1.17 \pm 0.06$ & $30.87 \pm 2.73$ & $12.63 \pm 0.71$ \\
\hline P. dubium & 0 & $77.75 \pm 5.18$ & $1.93 \pm 0.09$ & $69.76 \pm 8.11$ & $34.12 \pm 3.10$ \\
\hline \multirow[t]{4}{*}{ (Spreng.) Taub. } & 50 & $75.75 \pm 8.80$ & $1.87 \pm 0.18$ & $69.19 \pm 10.50$ & $34.25 \pm 0.70$ \\
\hline & 100 & $78.00 \pm 7.52$ & $1.88 \pm 0.19$ & $75.12 \pm 9.93$ & $32.44 \pm 4.73$ \\
\hline & 200 & $82.00 \pm 5.09$ & $1.96 \pm 0.08$ & $71.43 \pm 6.52$ & $38.50 \pm 2.51$ \\
\hline & 400 & $79.75 \pm 5.73$ & $1.94 \pm 0.11$ & $77.46 \pm 5.20$ & $38.90 \pm 9.50$ \\
\hline Mean & - & $78.65 \pm 2.35$ & $1.92 \pm 0.04$ & $72.60 \pm 4.57$ & $35.64 \pm 2.88$ \\
\hline \multirow[t]{5}{*}{ M. peruiferumL. f. } & 0 & $118.25 \pm 3.94$ & $1.48 \pm 0.03$ & $49.05 \pm 7.53$ & $18.32 \pm 3.51$ \\
\hline & 50 & $128.75 \pm 14.26$ & $1.40 \pm 0.26$ & $50.44 \pm 6.01$ & $17.88 \pm 2.46$ \\
\hline & 100 & $122.50 \pm 6.45$ & $1.46 \pm 0.20$ & $49.83 \pm 5.08$ & $21.92 \pm 4.92$ \\
\hline & 200 & $141.50 \pm 14.15$ & $1.68 \pm 0.23$ & $54.80 \pm 4.76$ & $19.14 \pm 4.08$ \\
\hline & 400 & $110.50 \pm 15.86$ & $1.45 \pm 0.06$ & $40.14 \pm 12.86$ & $18.73 \pm 4.20$ \\
\hline Mean & - & $124.30 \pm 11.68$ & $1.49 \pm 0.11$ & $48.85 \pm 5.36$ & $19.20 \pm 1.59$ \\
\hline
\end{tabular}

Each value indicates the mean per treatment \pm SE (n.4); ns*: Not significant at 5\% probability. (Source: the author)

stem diameter $(\mathrm{SD}=1.17 \mathrm{~cm})$, shoot dry matter $(\mathrm{SDM}=30.87$ g) and root dry matter (RDM=12.63 g). In P. dubium, $78.65 \mathrm{~cm}(\mathrm{H}), 1.92 \mathrm{~cm}(\mathrm{SD}), 72.60 \mathrm{~g}$ (SDM) and 35.64 $\mathrm{g}$ (RDM) were observed. In M. peruiferum plants, the mean values for the different variables were $124.30 \mathrm{~cm}$ (H), $1.49 \mathrm{~cm}$ (SD), $48.85 \mathrm{~g}(\mathrm{SDM})$ and $19.20 \mathrm{~g}$ (RDM) (Table 2).

\subsection{Chlorophyll content and antioxidant enzymes}

The content of chlorophyll "a" showed a peak at a $\mathrm{Cu}$ concentration of $100 \mathrm{mg} \mathrm{kg}^{-1}$ in all the tree species studied and, at concentrations of 200 and $400 \mathrm{mg} \mathrm{kg}^{-1}$, a reduction in the content of this pigment was observed in the plants (Figure 1A).

(Source: The author)
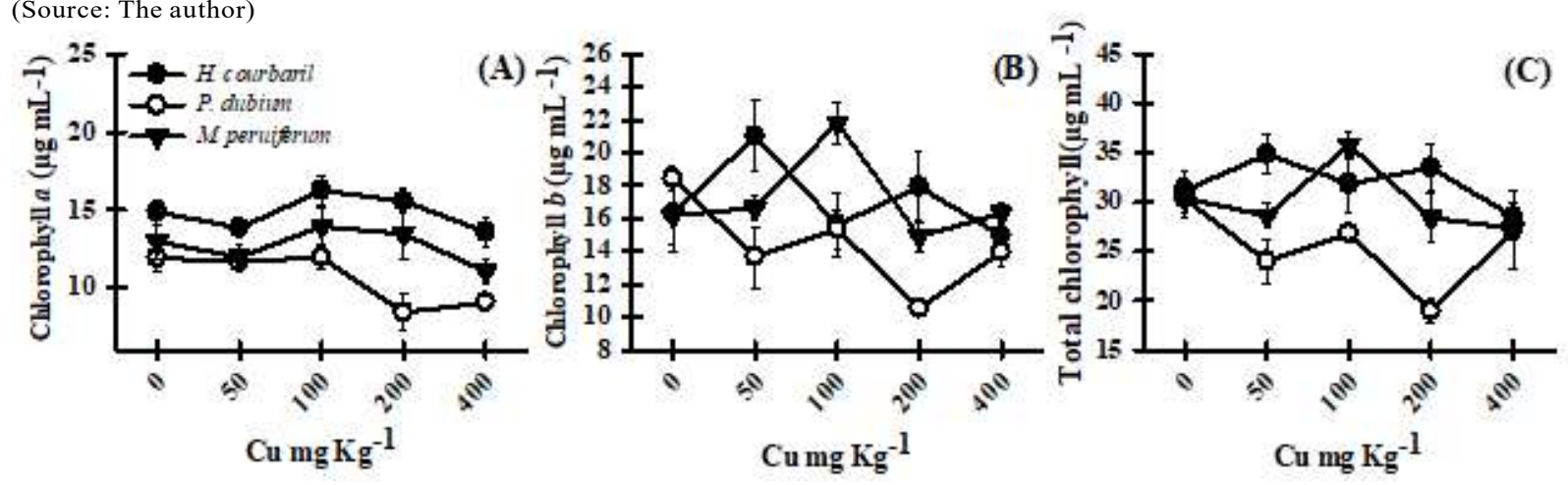

Figure 1 - Content of chlorophyll a (a), chlorophyll b (b) and total chlorophyll (c) for the species Hymenaea courbaril, Peltophorum dubium and Myroxylon peruiferum grown in soil with $\mathrm{Cu}$. Each value indicates the mean per treatment \pm SE.

Figura 1 - Teor de clorofila a (a), clorofila b (b) e clorofila total (c) para as espécies Hymenaea courbaril, Peltophorum dubium e Myroxylon peruiferum cultivadas em solo com Cu. Cada valor indica a média por tratamento $\pm S E$.

Revista Árvore. 2018;42(2):e420202 
Regarding chlorophyll "b", no common behavior was observed among the species studied. In H. courbaril, the content of chlorophyll " $b$ " was reduced from the concentration of $50 \mathrm{mg} \mathrm{Kg}^{-1}$. In $M$. peruiferum, the reduction in chlorophyll "b" was observed from 100 mg $\mathrm{Kg}^{-1}$. In P. dubium plants, the contents of chlorophyll "b" and total chlorophyll increased at higher concentrations (200 and $400 \mathrm{mg} \mathrm{Kg}^{-1}$ ). The curves for the content of total chlorophyll had a behavior similar to that observed for chlorophyll "b" (Figure 1B, 1C). In general, the leaves of the species under study showed a higher content of chlorophyll " $b$ " in relation to chlorophyll "a" (Figure 1A, 1B).
With the increase in $\mathrm{Cu}$ in the soil, $H$. courbaril plants showed an increase in the activity of catalase (CAT), when compared to the control plants (Figure 2C). SOD showed peak activity in the plants maintained in soil with $200 \mathrm{mg} \mathrm{Kg}^{-1} \mathrm{Cu}$, being inhibited at the highest $\mathrm{Cu}$ concentration in the soil $\left(400 \mathrm{mg} \mathrm{Kg}^{-1}\right)$. Even with $\mathrm{Cu}$ increase in the soil, APX showed similar activity to that observed in the control plants (Figure 2B). It is noteworthy that guaiacol peroxidase (GPX) did not show activity, and that CAT was probably the main enzyme responsible for preventing oxidative stress in this species (Figure 2C, 2D).

(Source: The author)
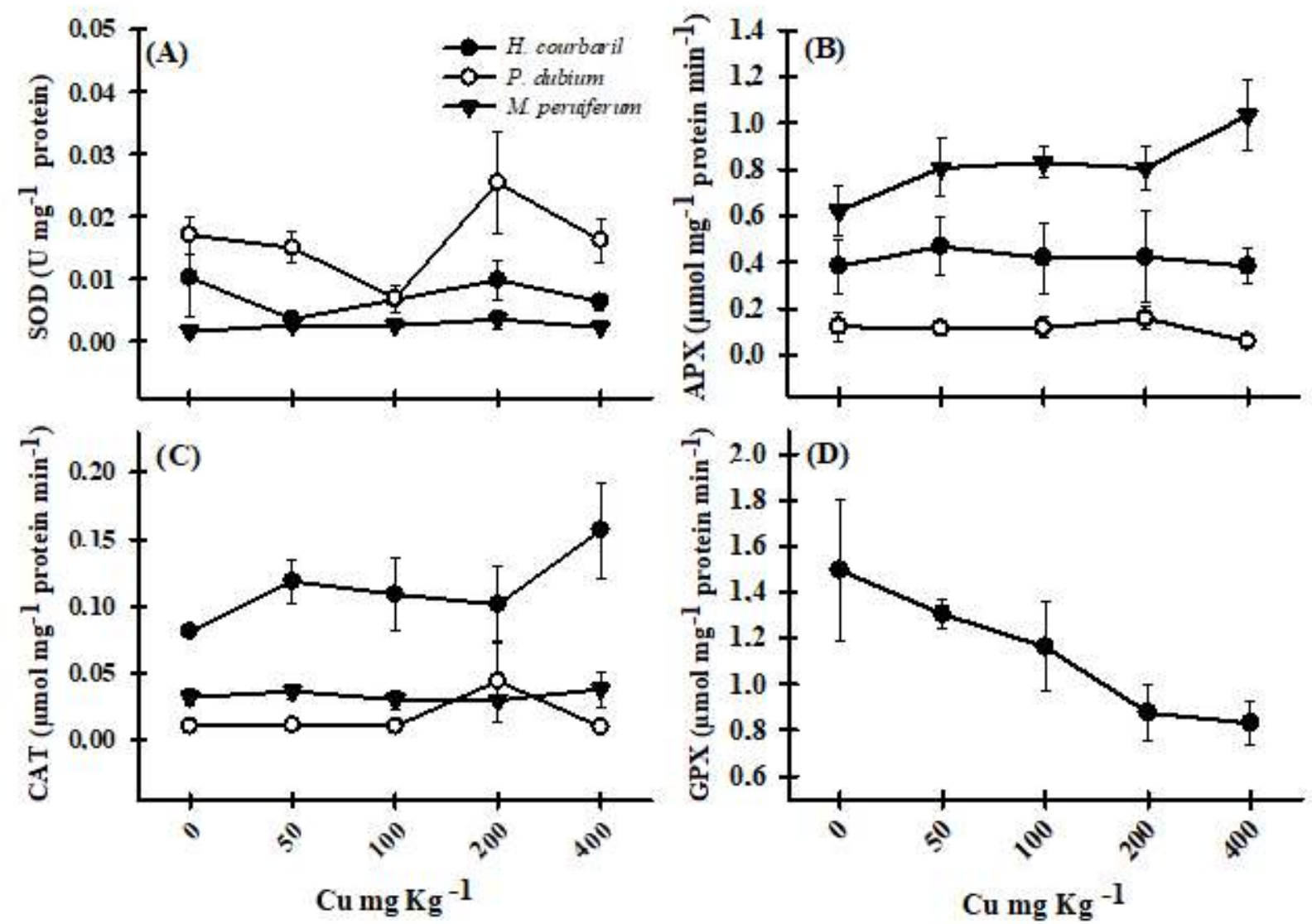

Figure 2 - Activity of antioxidant enzymes (A) superoxide dismutase (SOD), (B) ascorbate peroxidase (APX), (C) catalase (CAT) and (D) guaiacol peroxidase (GPX) for the species Hymenaea courbaril, Peltophorum dubium and Myroxylon peruiferum grown in soil with $\mathrm{Cu}$.

Figura 2 - Atividade das enzimas antioxidantes (A) dismutase do superóxido (SOD), (B) peroxidase do ascorbato (APX), (C) catalase (CAT) e (D) peroxidase do guaiacol (GPX) das espécies Hymenaea courbaril, Peltophorum dubium. e Myroxylon peruiferum cultivadas em solo com $\mathrm{Cu}$. 
In $P$. dubium, a high activity of SOD and CAT was observed in plants growing in soil at a concentration of $200 \mathrm{mg} \mathrm{Kg}^{-1} \mathrm{Cu}$, being inhibited at the concentration of $400 \mathrm{mg} \mathrm{Kg}^{-1}$. APX activity was similar to the control plants (Figure 2A, 2B, 2C). GPX also showed no activity in the evaluated plants (Figure 2D). Thus, it can be observed that SOD and CAT were the main enzymes responsible for the elimination of reactive oxygen species (ROS) for this species (Figure 2A, 2C).

M. peruiferum plants showed higher APX activity, especially at the highest $\mathrm{Cu}$ concentrations in the soil, and an increase in GPX up to the concentration of 50 $\mathrm{mg} \mathrm{Kg}^{-1}$ was observed, followed by inhibition and decline with increasing $\mathrm{Cu}$ concentrations (Figure 2B, 2D). SOD and CAT had constant activity, similar to the plants submitted to the control treatment (Figure 2A, 2C). For this species, the high APX activity showed that it was the main enzyme in preventing oxidative stress (Figure 2B).

\subsection{Cu content in the plants}

In general, $\mathrm{Cu}$ bioaccumulation in the species occurred in the plant root system. Increased $\mathrm{Cu}$ accumulation was observed in plants growing in soils treated with $400 \mathrm{mg} \mathrm{Kg}^{-1}$ of the element; H. courbaril accumulated $4.39 \mathrm{mg} \mathrm{plant}^{-1}$, P. dubium $5.56 \mathrm{mg} \mathrm{plant}^{-1}$ and
M. peruiferum $1.56 \mathrm{mg} \mathrm{plant}^{-1}$ (Figure 3 ). H. courbaril had 56 to $92 \%$ of the copper retained in the roots, and the same behavior was observed for P. dubium (7791\%) and $M$. peruiferum (19-64\%).

Regarding the total copper content, $H$. courbaril plants had a linear increase in this chemical element in the tissues with the increase in copper concentrations in the soil (Figure 3). P. dubium had a quadratic behavior, showing high $\mathrm{Cu}$ contents in the tissues of plants grown in soils with $\mathrm{Cu}\left(400 \mathrm{mg} \mathrm{Kg}^{-1}\right)$, bioaccumulating $\mathrm{Cu}$ in all tissues, mainly in the roots, reaching $4.47 \mathrm{mg}$ $\mathrm{kg}^{-1}$ (Figure 3). M. peruiferum showed a linear behavior, with an increase in $\mathrm{Cu}$ contents in the tissues with increasing $\mathrm{Cu}$ concentrations in the soil (Figure 3 ).

\section{DISCUSSION}

Copper is an essential micronutrient to plants but, at high concentrations, above $200 \mathrm{mg} \mathrm{Kg}^{-1}$ in the soil, it causes pollution and can be toxic to plants, with potential direct or indirect risk to human health, when exposed to this scenario (CETESB, 2005). High levels of this metal in the soil are potentially toxic to most plants, with leaf chlorosis and growth inhibition as visible symptoms of $\mathrm{Cu}$ toxicity. However, in this study, these symptoms were not observed, even when the plants were exposed to high concentrations of this

(Source: The author)

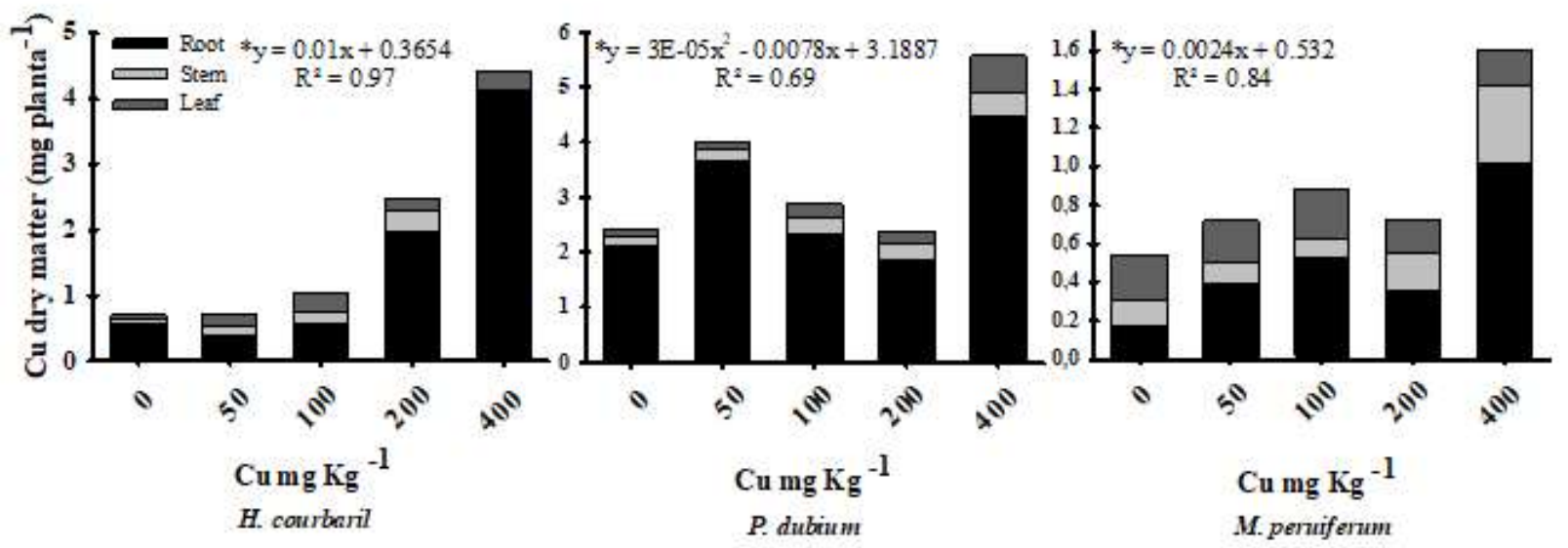

Figure 3 - Cu bioaccumulated in different plant organs of Hymenaea courbaril, Peltophorum dubium and Myroxylon peruiferum, depending on the concentrations of the element applied to the soil. Each value indicates the mean per treatment $\pm \mathrm{SE}$.

Figura 3 - Cu bioacumulado nos diferentes órgãos das plantas de Hymenaea courbaril, Peltophorum dubium e Myroxylon peruiferum em função das concentrações do elemento aplicado no solo. Cada valor indica a média do tratamento $\pm S E$.

Revista Árvore. 2018;42(2):e420202 
element in the soil (Table 2). This result is similar to that found by Cambrollé et al. (2013), working with wild vine growing on copper-contaminated soils.

$\mathrm{Cu}$ toxicity decreases biosynthesis, besides reducing chlorophyll content, due to damage to thylakoid membranes (Adrees et al., 2015). Several authors (MateosNaranjo et al., 2008; Gomes et al., 2011; Yruela, 2013; Nair et al., 2014; Adrees et al., 2015) reported the effect of excess copper on chlorophyll, resulting in the degradation of this pigment, which is in agreement with the results found in this research. However, in tolerant plants, chlorophyll content increases or does not undergo significant changes in response to the treatment with heavy metals (Borghi et al., 2008).

In the three species studied, there was a reduction trend in the levels of "a", "b" and total chlorophyll in the plants for the highest $\mathrm{Cu}$ concentration in the soil (400 $\mathrm{mg} \mathrm{kg}^{-1}$ ), when compared to the plants of the control treatment. However, no visible chlorosis symptoms were observed in the leaves and plant growth was not adversely affected. It is possible that this result is related to the mechanisms that these plants used to prevent $\mathrm{Cu}$ translocation to the shoot, accumulating heavy metal in the root system, indicating a higher tolerance of these species to $\mathrm{Cu}$.

The data in this study showed a higher content of chlorophyll "b" in relation to chlorophyll "a" in the leaves of the studied species, which is not common, since chlorophyll "b" is an accessory pigment. This response is possibly related to the fact that these plants are in a greenhouse, growing in a shaded environment, and may have some kind of compensatory mechanism, since the use of meshes reduces the luminous intensity in relation to full sun by $50 \%$. The studied species probably invested in the production of pigments in an attempt to increase diffuse light capture and maintain photosynthetic rates. Leaves growing in shaded environments have a greater amount of chlorophyll "b", which is important to play a role in the absorption of diffuse radiation (Huang et al., 2016). Studies by Chang et al. (2016) with dragon fruit (Hylocereus polyrhizus (Weber) Britt. \& Rose) plants report an increase in chlorophyll content, mainly chlorophyll "b" in relation to chlorophyll "a", with plants kept in different degrees of shading.

Another possible justification for the content of chlorophyll "b" being greater than chlorophyll "a" may be due to foliar senescence or some abiotic stress, such as the presence of heavy metals in the soil (Hörtensteiner, 2013). Mulisch and Krupinska (2013) reported that, in most cases of leaf senescence due to environmental stress, chlorophyll " $a$ " is the first to be degraded. One of the mechanisms that performs this degradation is pheophorbide á oxygenase - PAO (Hörtensteiner and Kräutler 2011). In order for this metabolic pathway PAO to degrade chlorophyll "b", its conversion to chlorophyll "a" is necessary (Hörtensteiner, 2013). In this study, the species were kept under nursery conditions for a few months, and it may have occurred that, at the moment the leaves were sampled for pigment evaluation, they were in the initial senescence stage, resulting in a higher content of chlorophyll " $b$ " in relation to chlorophyll "a".

Excess $\mathrm{Cu}$ can cause oxidative stress in plants due to increased production of highly toxic oxygen free radicals (Yruela, 2009). Reactive oxygen species (ROS), such as superoxide radicals $\left(\mathrm{O}_{2}^{-}\right)$, hydrogen peroxide $\left(\mathrm{H}_{2} \mathrm{O}_{2}\right)$ and the hydroxyl radical $\left(\mathrm{OH}^{*}\right)$, cause damage to proteins and lipids of plant cell membranes (Thounaojam et al., 2012; Sánchez-Pardo et al., 2014). To prevent the production of ROS, plants have antioxidant mechanisms that include antioxidant enzymes such as superoxide dismutase (SOD), ascorbate peroxidase (APX), catalase (CAT), and guaiacol peroxidase (GPX), therefore preventing oxidative damage (Adrees et al., 2015). It is important to note that APX activity was higher to that of CAT for all species studied. This is due to the fact that, although CAT has high specificity for $\mathrm{H}_{2} \mathrm{O}_{2}$, its affinity is lower than that of APX (Meng et al., 2007; Sharma et al., 2012), being less efficient in the removal of $\mathrm{H}_{2} \mathrm{O}_{2}$, which possibly explains its lower activity in relation to APX.

H. courbaril plants showed increased CAT activity, from the lowest copper concentration ( $\left.50 \mathrm{mg} \mathrm{Kg}^{-1}\right)$. CAT is sensitive to copper stress which, at low concentrations, may stimulate the activity of this enzyme (Srivastava et al., 2006). It is interesting to observe that $H$. courbaril had compensatory defense mechanisms against oxidative stress (Cargnelutti et al., 2006), where CAT was the main enzyme.

The increase in the activity of SOD in the studied species, at the concentration of $200 \mathrm{mg} \mathrm{Kg}^{-1}$, can be attributed to the accumulation of superoxide radicals $\left(\mathrm{O}_{2}^{-}\right)$induced by copper. To catalyze the dismutation of the superoxide anion, which is the first ROS formed, SOD participates in the first line of defense against 
oxidative stress (Gill and Tuteja, 2010). In addition, the removal of the superoxide radical by SOD is important to prevent the formation of hydroxyl radicals before their interaction with target molecules occurs (Xu et al., 2013).

For M. peruiferum plants, among the enzymes under study, APX played the main role in the removal of ROS. Lyubenova et al. (2015) reported increased APX in increasing $\mathrm{Cu}$ concentrations for Typha latifolia. However, the activity of antioxidant enzymes can be increased to a certain level and then decreased due to the increase in oxidative stress (Adrees et al., 2015), and this behavior was observed in P. dubium plants at the highest $\mathrm{Cu}$ concentration in the soil, for the enzymes CAT, SOD and APX.

Metal absorption by the plant depends on the availability of the soil metals and the physiological requirement of the plant (Dalcorso et al., 2014). Cu is absorbed by active transport and $\mathrm{Cu}$ ions tend to accumulate in the root system, mainly in protoplasms (Malavolta, 2006; Palmer and Gerinot, 2009). There are several proteins that are responsible for transporting these metallic ions to the cell membrane, such as Ptype ATPase, COPT and chaperones (Yruela, 2005).

The three species studied were able to extract $\mathrm{Cu}$ from the soil and concentrate it in all studied organs: leaves, stems and roots. In the three species, copper bioaccumulation occurred mainly in the root system, and an increase in $\mathrm{Cu}$ contents in the tissue was observed with an increase in $\mathrm{Cu}$ concentrations in the soil. A study conducted with the species Peltophorum dubium, Parapiptadenia rígida, Enterolobium contortisiliquum (Silva et al., 2011), Bauhinia forficata Link, Pterogyne nitens Tul (Silva et al., 2015) and two apple cultivars (Malus hupehensis Rehd.) (Wang et al., 2016) showed that $\mathrm{Cu}$ accumulates preferentially in the root system, a result similar to that found in this study.

Copper accumulation in the root system may represent a tolerance strategy of the plant to the excess of heavy metal in the soil (Silva et al., 2011; Cambrollé et al., 2013), aiming at preserving the most metabolically active tissues (Branzini et al., 2012) and the photosynthetic machinery present in the leaves. Another possible explanation would be the apoplastic barriers of the exoderm and endoderm, since they play an important role in plant protection, minimizing metal translocation from the roots to the shoot (Gomes et

Revista Árvore. 2018;42(2):e420202 al., 2011; Freitas et al., 2015). Cell wall thickening in the root system provides a greater retention area of heavy metals, reducing their translocation to the shoot (Adrees et al., 2015). Wang et al. (2106) worked with the cultivar Malus hupehensis Rehd. Ralls, and reported higher amounts of $\mathrm{Cu}$ sequestered mainly in the cell wall and vacuole of fibrous roots.

\section{CONCLUSION}

The growth of species $H$. courbaril, $P$. dubium and $M$. pereuiferum is not affected by the high $\mathrm{Cu}$ concentrations applied to the soil. In the studied species, the damage from excess $\mathrm{Cu}$ in the soil is prevented due to the increase in the activity of some enzymes of the antioxidant system and the accumulation of this heavy metal in the plant root system.

\section{ACKNOWLEDGEMENTS}

The authors of this study would like to thank Cooperativa Regional de Cafeicultores de Guaxupé (Cooxupé) for plant tissue analyses. Financial support FAPEMIG.

\section{REFERENCES}

Ali H, Khan E, Sajad MA. Phytoremediation of heavy metals - concepts and applications. Chemosphere. 2013;91(7):869-81.

Adrees M, Ali S, Rizwan M, Ibrahim M, Abbas F, Farid M. et al. The effect of excess copper on growth and physiology of important food crops: a review: Environmetal Science and Pollution Research International. 2015;22:8148-62.

Arnon DI. Copper enzymes in isolated chloroplasts. Polyphenoloxidase in Beta vulgaris. Plant Physiology. 1949;24:1-15.

Borghi M, Tognetti R, Monteforti G, Sebastiani L. Responses of two poplar species (Populus alba and Populus $\mathrm{x}$ canadensis) to high copper concentrations. Environmental and Experimental Botany. 2008;62(3):290-9.

Bradford M. Rapid and quantative method for quantitation of microgram quantities of protein utilizing the principle of protein-dye binding. Anual Biochemistry. 1976;72:284-352.

Branzini A, González RS, Zubillaga M. Absorption and translocation of copper, zinc and chromium

Revista Árvore. 2018;42(2):e420202 
by Sesbania virgata. Journal of Environmental Management. 2012;102:50-4.

Cambrollé J, García JL, Ocete R, Figueroa ME, Cantos M. Growth and photosynthetic responses to copper in wild grapevine. Chemosphere. 2013;93(2):294-301.

Carmo CAFS, Araujo WS, Bernardi ACC, Saldanha MFC. Métodos de análise de tecidos vegetais utilizados na Embrapa Solos. Rio de Janeiro: Embrapa Solos; 2000.

Cargnelutti D, Tabaldi LA, Spanevello RM, Oliveira JG, Battisti V, Redin M. et al. Mercury toxicity induces oxidative stress in growing cucumber seedlings. Chemosphere. 2006;65:999-1006.

Companhia de Tecnologia de Saneamento Ambiental - CETESB. Valores orientados para solos e águas subterrâneas no estado de São Paulo-2005. No 195-2005-E, de 23 de nov. de 2005.

Chang P, Hsieh C, Jiang Y. Responses of 'Shih Huo Chuan'pitaya (Hylocereus polyrhizus (Weber) Britt. $\&$ Rose) to different degrees of shading nets. Scientia Horticulturae. 2016;198:154-62.

Dalcorso G, Manara A, Piasentin S, Furini A. Nutrient metal elements in plants. Metallomics. 2014:6(10):1770-88.

Freitas TA, França MGC, Almeida AAF, Oliveira SJR, Jesus RM, Souza VL. et al. Morphology, ultrastructure and mineral uptake is affected by copper toxicity in young plants of Inga subnuda subs. luschnathiana (Benth.) TD

Penn. Environmental Science and Pollution Research. 2015;22(20):15479-94.

Gao S, Ou-Yang C, Tang L, Zhu JQ, Xu Y, Wang $\mathrm{SH}$ et al. Growth and antioxidant responses in Jatropha curcas seedling exposed to mercury toxicity. Journal of Hazardous Materials. 2010:182(1):591-7.

Gautam S, Anjani K, Srivastava N. In vitro evaluation of excess copper affecting seedlings and their biochemical characteristics in Carthamus tinctorius L.(variety PBNS-12). Physiology and Molecular Biology of Plants. 2016;22(1):121-9.
Giannopolitis CN, Ries SK. Superoxide dismutases I: occurrence in higher plants.Plant Physiology.1977;59:309-14.

Gill SS, Tuteja N. Reactive oxygen species and antioxidant machinery in abiotic stress tolerance in crop plants. Plant Physiology and Biochemistry. 2010:48(12):909-30.

Gomes MP, Marques TCLLD, Melo S, Nogueira MDOG, Castro EMD, Soares ÂM.

Ecophysiological and anatomical changes due to uptake and accumulation of heavy metal in Brachiaria decumbens. Scientia Agricola. 2011;68(5):566-73.

Havir EA, Mchale NA. Biochemical and developmental characterization of multiple forms of catalase in tobacco leaves. Plant Physiology. 1987;84:450-5.

Hossain MA, Piyatida P, Silva JAT, Fujita M. Molecular mechanism of heavy metal toxicity and tolerance in plants: central role of glutathione in detoxification of reactive oxygen species and methylglyoxal and in heavy metal chelation. Journal of Botany [Internet]. 2012. Article ID 872875.

Hörtensteiner S, Kräutler B. Chlorophyll breakdown in higher plants. Biochimica et Biophysica Acta (BBA)-Bioenergetics. 2011;1807(8):977-88.

Hörtensteiner S. Update on the biochemistry of chlorophyll breakdown. Plant Molecular Biology. 2013;82(6):505-17.

Huang CJ, Wei G, Jie YC, Xu JJ, Anjum SA, Tanveer M. Effect of shade on plant traits, gas exchange and chlorophyll content in four ramie cultivars. Photosynthetica. 2016;54(3):390-5.

Lin J, Wang G. Doubled $\mathrm{CO}_{2}$ could improve the drought tolerance better in sensitive cultivars than in tolerant cultivars in spring wheat. Plant Science. 2002;163:627-37.

Lyubenova L, Bipuah H, Belford E, Michalke B, Winkler B, Schröder P. Comparative study on the impact of copper sulphate and copper nitrate on the detoxification mechanisms in Typha latifolia. Environmental Science and Pollution Research. 2015;22(1):657-66. 
Malavolta E. Manual de nutrição mineral de plantas. Piracicaba: Ceres; 2006.

Malik N, Biswas AK. Role of higher plants in remediation of metal contaminated sites. Scientific Reviews and Chemical Communications. 2012;2(2):141-6

Marschner H. Mineral nutrition of higher plants. London: Academic Press; 1995.

Mateos-Naranjo E, Redondo-Gómez S, Cambrollé J, Figueroa ME. Growth and photosynthetic responses to copper stress of an invasive cordgrass, Spartina densiflora. Marine Environmental Research. 2008;66(4):459-65.

Mateos-Naranjo E, Andrades-Moreno L, Cambrollé J, Perez-Martin A. Assessing the effect of copper on growth, copper accumulation and physiological responses of grazing species Atriplex halimus: Ecotoxicological implications. Ecotoxicology and Environmental Safety. 2013;90:136-42.

Meng Q, Zou J, Zou J, Jiang W, Liu D. Effect of $\mathrm{Cu}^{2+}$ concentration on growth, antioxidant enzyme activity and malondialdehyde content in garlic (Allium sativum L.). Acta Biologica Cracoviensia Series Botanica. 2007;49(1):95-101.

Moraes RM, Santos Filho PR, Carvalho M, Nogueira ML, Barbosa S. Effects of copper on physiological and cytological aspects in Lactuca sativa L. Revista Brasileira de Biociências. 2015;13(2):115-21.

Mulisch M, Krupinska K. Ultrastructural analyses of senescence associated dismantling of chloroplasts revisited. In: Krupinska K, Biswal UC. editors. Plastid development in leaves during growth and senescence. Springer; 2013. p.307-31.

Nagajyoti PC, Lee KD, Sreekanth TVM. Heavy metals, occurrence and toxicity for plants: a review. Environmental Chemistry Letters. 2010;8(3):199-216.

Nair PMG, Kim S, Chung IM. Copper oxide nanoparticle toxicity in mung bean (Vigna radiata L.) seedlings: physiological and molecular level responses of in vitro grown plants. Acta Physiologiae Plantarum. 2014;36(11):2947-58.
Nakano Y, Asada K. Hydrogen peroxide is scavenged by ascorbato-specific peroxidase in spinach chloroplasts. Plant Cell Physiology. 1981;22:867-80.

Palmer CM, Guerinot ML. Facing the challenges of $\mathrm{Cu}, \mathrm{Fe}$ and $\mathrm{Zn}$ homeostasis in plants. Nature Chemical Biology. 2009;5(5):333-40.

Sánchez-Pardo B, Fernández-Pascual M, Zornoza P. Copper microlocalisation and changes in leaf morphology, chloroplast ultrastructure and antioxidative response in white lupin and soybean grown in copper excess. Journal of Plant Research. 2014;127:119-29.

Sharma P, Jha AB, Dubey RS, Pessarakli M. Reactive oxygen species, oxidative damage, and antioxidative defense mechanism in plants under stressful conditions. Journal of Botany. 2012;2012:1-26.

Sheoran V, Sheoran AS, Poonia P. Role of hyperaccumulators in phytoextraction of metals from contaminated mining sites: a review. Critical Reviews in Environmental Science and Technology. 2010;41(2):168-214.

Silva RF, Lupatini M, Antoniolli ZI, Leal LT, M Junior CA. Comportamento de Peltophorum dubium (Spreng.) Taub., Parapiptadenia rigida (Benth.) Brenan e Enterolobium contortisiliquum (Vell.) Morong cultivadas em solo contaminado com cobre. Ciência Florestal. 2011;21(1):103-10.

Silva RF, Ros COD, Scheid DL, Grolli AL, Marco RD, Missio EL. Copper translocation and tolerance in seedlings of tree species grown in contaminated soil. Revista Brasileira de Engenharia Agrícola e Ambiental. 2015;19(11):1093-9.

Souza TC, Castro EM, Magalhães PC, Alves ET, Pereira FJ. Early characterization of maize plants in selection cycles under soil flooding. Plant Breeding. 2012;131(4):493-501.

Srivastava S, Mishra S, Tripathi RD, Dwivedi S, Gupta DK. Copper-induced stress and responses of antioxidants and pthyochelatins in Hydrilla verticillata (L.) Royle. Aquatic Toxicology. 2006;80(4):405-15.

Stankovic S, Kalaba P, Stankovic AR. Biota as toxic metal indicators. Environmental Chemistry Letters. 2014;12:63-84.

Revista Árvore. 2018;42(2):e420202 
Thounaojam TC, Panda P, Mazumdar P, Kumar D, Sharma GD, Sahoo L, Sanjib P. Excess copper induced oxidative stress and response of antioxidants in rice. Plant Physiology and Biochemistry. 2012;53:33-9.

Wang QY, Liu JS, Hu B. Integration of copper subcellular distribution and chemical forms to understand copper toxicity in apple trees. Environmental and Experimental Botany. 2016;123:125-31.

Xu J, Duan X, Yang J, Beeching JR, Zhang P. Enhanced reactive oxygen species scavenging by overproduction of superoxide dismutase and catalase delays postharvest physiological deterioration of cassava storage roots. Plant Physiology. 2013;161(3):1517-28.

Yruela I. Copper in plants. Brazilian Journal of Plant Physiology. 2005:17(1):145-56.

Yruela I. Copper in plants: acquisition, transport and interactions. Functional Plant Biology. 2009;36(5):409-30.

Yruela I. Transition metals in plant photosynthesis. Metallomics. 2013;5(9):1090-109. 